DOI: https://doi.org//10.32839/2304-5809/2020-79.2-23

UDC $82.091=111=161.2$

Stupnytska Halyna

Drohobych Ivan Franko State Pedagogical University

\title{
MORAL VALUES OF THE CHARACTERS IN ENGLISH AND UKRAINIAN COMEDY ART
}

Summary. In the article the attempt has been made to characterize personal collisions, the evolution of moral search of the characters in English and Ukrainian comedy art at the turn of the 19th and 20th centuries, mainly in the plays «The Wise Man and the Fool» by I. Karpenko-Karyi, "An Ideal Husband» by O. Wilde and "Arms and the Man» by B. Shaw. The playwrights focused their attention on the process of spiritual needs change, perception and comprehension of the world around them. Arthur Goring, Robert Chiltern, captain Bluntschli, Raina Petkoff, Sergius Saranoff reveal alogisms of customary and ordinary things in life, laugh at the absurdness of established stereotypes. The above-mentioned literary personages reflect dominant features of the national character, oppose moral degradation, self-adoration, vanity of the mercantile part of the society. The psychology of social relations has been investigated paying great attention to the worldview confrontation of comedy characters. The main sphere of the writers' thoughts was connected with the themes of the spiritual solitude of a person, discrediting of moral values, the position of women in the society, the power of money, family relations, marital fidelity, friendship. The transformation of understanding of transcendental ideals took place. Typological similarities and differences in the depiction of the created personages in the examined text structures have been concretized. In the social comedy «The Wise Man and the Fool» moral values of the characters have been represented in a contrast way, social and cultural relations of people at the turn of the centuries that are of typical nature have been examined. The principal personages of the plays "An Ideal Husband» and "Arms and the Man" revalue their life positions. O. Wilde and B. Shaw reflected a close connection of the situational comicality with elements of the life dramatic effect asserting a vital, active way of living but not a passive result. In the characters' discussions mockery, irony, sharp wit are concealed and become a peculiar form of consolidation of a free person's rights, his protest against his own enthralment.

Keywords: English and Ukrainian comedy, the discourse of personality, moral values, personal collisions of the characters, psychology of social relations, dominant features of the national character, comicality.

Ступницька Г.I. Дрогобицький державний педагогічний університет імені Івана Франка

\section{МОРАЛЬНІ ЦІННОСТІ ДІЙОВИХ ОСІБ В АНГЛІЙСЬКІЙ ТА УКРАЇНСЬКІЙ КОМЕДІОГРАФІЇ}

Анотація. У статті здійснено спробу охарактеризувати особистісні колізії, еволюцію моральних пошуків дійових осіб в англійській та українській комедіографрії на зламі XIX-XX століть, зокрема у п’есах «Розумний і дурень» I. Карпенка-Карого, «Ідеальний чоловік» О. Вайлда та «Зброя і людина» Б. Шоу. Драматурги фокусували увагу на процесі зміни духовних потреб, сприйняття та розуміння навколишнього світу. Артур Горінг, Роберт Чілтерн, капітан Блюнчлі, Райна Петкова, Сергіус Саранов виявляють алогізми звичного та повсякденного в житті, сміються над недолугістю усталених стереотипів. Згадані літературні персонажі відображають домінантні ознаки нащіонального характеру, протистоять моральній розбещеності, самозакоханості, суєтності меркантильної частини суспільства. Розглянуто психологію суспільних відносин, увиразнивши світоглядне протистояння комедійних персонажів. Провідна сфера роздумів драматургів пов'язана з темами духовної самотності особистості, дискредитації моральних цінностей, становища жінок у суспільстві, влади грошей, подружньої вірності, родинних стосунків, дружби. Відбувалася трансформація розуміння трансцендентних ідеалів. Конкретизовано типологічні збіги та розбіжності в окресленні створених дійових осіб у досліджуваних текстових структурах. У соціально-побутовій комедії «Розумний і дурень» контрастно зображено ціннісні орієнтації дійових осіб, увиразнено соціальні та культурні відносини людей на рубежі століть, що мають типовий характер. Центральні персонажі п’ес «Ддеальний чоловік» та «Зброя і людина» здійснюють переоцінку життевої позиції. О. Вайлд та Б. Шоу відобразили тісний взаємозв'язок ситуативного комізму з елементами життевого драматизму, відстоюючи життездатний, активний спосіб існування, а не пасивний результат. У дискусіях персонажів прихована насмішка, іронія, дотепність, що постають своєрідною формою утвердження прав вільної особистості, їі протесту проти власного поневолення. Йдеться не про одну подієву лінію видимих сутичок між дійовими особами, а про поліфонічну систему конфліктів, обумовлену життевими колізіями. В аналізованих комедіях англійські драматурги увиразнили новаторські тенденції психологічного характеротворення, вказували на важливість ціннісних орієнтацій, що спонукали до відтворення підсвідомого стосовно пізнання людського життя та інтерпретації навколишньої дійсності.

Ключові слова: англійська та українська комедія, дискурс особистості, моральні цінності, особистісні колізії персонажів, психологія суспільних відносин, домінантні ознаки національного характеру, комізм.

The problem setting. In the comedies «The Philanderer» (1893), "Arms and the Man» (1894), «Man and Superman» (1903) by B. Shaw, "A Woman of No Importance» (1893), «The Importance of Being Earnest» (1895), «An Ideal Husband» (1895) by O. Wilde, «The Wise Man and the Fool»
(1885), «The Master» (1900), «Vanity» (1903), «The Sea of Life» (1904) by I. Karpenko-Karyi, «Chasing Two Hares» (1883) by M. Starytskyi, «To Be Duped» (1881), «The Opposite Streams» (1900) by M. Kropyvnytskyi, «The Teacher» (1894) by I. Franko social and ethical sense of human life in the light of 
laughter culture is interpreted, complications and paradoxes of the human existence are depicted. The investigated plays strengthen moral standards exposing faults, characteristic defects of the epoch. In their works the authors used kind humour, ironical laughter, scathing satire.

The increasing interest in the relations of the personality and society in the comedies is explained by a greater attention to the dependence of a person's fate on the surrounding world in English and Ukrainian literature of the late $19^{\text {th }}$ and early $20^{\text {th }}$ centuries. This period of time was marked by the tendency that concentrated much attention to showing the contrasts and paradoxes of life in the playwrights' plays. The main sphere of the writers' thoughts was connected with the themes of the spiritual solitude of a person, discrediting of moral values, the position of women in the society, the power of money, family relations, friendship. The transformation of transcendental ideals comprehension took place.

The analysis of the investigations and published works. The detailed literary researches by P. Balashov [2], D. Gordon [25], A. Henderson [26], S. Khorob [24], P. Letnianchyn [12], N. Maliutina [15], L. Moroz [18], A. Obraztsova [19], V. Panchenko [20], V. Pratsiovytyi [21], M. Sokolianskyi [22], V. Vyshynskyi [3], A. Zakharchenko [4], M. Zymomrya [5] are dedicated to the investigation of the discourse of personality in English and Ukrainian dramaturgy at the turn of the $19^{\text {th }}-20^{\text {th }}$ centuries.

Despite sound researches, in Ukrainian Literature Studies there is no comparative analysis of the image of a person in the light of moral values in the comedies «The Wise Man and the Fool» by I. Karpenko-Karyi, «An Ideal Husband» by O. Wilde and "Arms and the Man" by B. Shaw that becomes the object of the investigation and determines the novelty of the article.

Aim setting. The objective of the work is to analyze the discourse of personality in the light of moral values in English and Ukrainian comedy art. The outlined objective requires the fulfillment of the following tasks: to discover dominant features of images-characters in the analyzed plays; to characterize personal conflicts, the evolution of moral search of a person in the mentioned comedy works; to show the psychology of social relations; to concretize typological similarities and differences in the depiction of the created personages on the pages of the plays «The Wise Man and the Fool» by I. Karpenko-Karyi, "An Ideal Husband» by O. Wilde and "Arms and the Man» by B. Shaw.

The presentation of the main material. Literary interpretations of the personality in the comedies of B. Shaw, O. Wilde, M. Kropyvnytskyi, M. Starytskyi, I. Karpenko-Karyi, I. Franko are characterized by a number of similarities and differences. They are determined by realistic substratum of the dramatists' artistic thinking. Its predominant ideas in the comedies "Arms and the Man», "An Ideal Husband», "The Importance of Being Earnest», "The Opposite Streams», "Chasing Two Hares», "The Sea of Life», "The Teacher» have a direct effect on representing individual peculiarities of a person. Reinterpretation of the established structures of character formation concentrates the recipient's attention on new models of the human behaviour that widely reflects spiritual desires of people in the late $19^{\text {th }}$ and early $20^{\text {th }}$ centuries.

Literary interests of English and Ukrainian playwrights include social and even more psychological problems. The result is the aspiration to comprehend the mystery of the human psyche, subconscious structures, interest in the psychological analysis. So the author of a realistic work, «aiming at the exactness of the picture mustn't be a registrar or a historian but must apprehend realia from appropriate world view positions that cognitive directive doesn't come to fixed information because it is directed to the depiction of characters, the whole spiritual life of the individuality" [13, p. 306].

In the comedies «The Wise Man and the Fool» by I. Karpenko-Karyi, "An Ideal Husband» by O. Wilde, "Arms and the Man» by B. Shaw the dramatists express an opinion of discordant nature of a person, his character which is easier to understand in connection with the writers' world views. They are based on the system of values that result from the best achievements of the humane thought.

The play "The Wise Man and the Fool» is characterized by the social direction, psychological and ethical generalizations. The comedy shows the writer's artistic research of the reasons for the spiritual decline of a person under the influence of temptation, arrogance and power of money. The main character of the analyzed work Mykhailo Okun' is a hard-hearted knave who tries to become prosperous at all costs. He craftily drives away his brother Danylo, doesn't support his father who is at a loss. Later the boy tempts his brother's fiancée and marries her having self-interested plans:

«Михайло. Жалко, що ти посивієш в дівках.

Мар'яна. Не журись! I рік не пройде, як ми поберемось з Данилом.

Михайло. Дурна!.. А я розумнішою тебе лічив... Чи не краще ж не ждать, не горювать, а хоч завтра йти до мене панувать.

Мар'яна. Татові скажи! Яке велике щастя жить 3 тобою і бути по-сміхом для усього села!

Михайло. Хто ж посміє сміятися з моєї жінки! Мар'яна. Жінки?.

Обоє мовчать.

Михайло. Кажи, покинеш Данила, підеш за мене?

Мар'яна (лукаво). Гум!.. Побачимо... Сватай!» $[14$, c. $162-163]$.

Mykhailo's brother Danylo Okun', the embodiment of virtues and conscience, is responsible, honest, intelligent, deeply respects and sympathizes with his close and distant relatives, acquaintances. But the fellow has to earn money abroad, loses his darling and his father's trust to a great extent because of his brother's covetousness and perfidy.

The English playwright O. Wilde in the comedy "An Ideal Husband" also touches upon the theme of power of money, one of eternal themes of art, researches the psychology of family relations, friendship. One of the principal characters of the play sir Robert Chiltern aspires to power, fame, wealth. But, in contrast to Mykhailo Okun', a dishonest action in his youth that had helped him to become rich, didn't have an effect on the further noble life of the Under-Secretary for Foreign Affairs.

In the work the author widely develops the conflict between Robert Chiltern and Mrs. Cheveley as 
to their discordant intentions. The Under-Secretary for Foreign Affairs' duty is to study the expediency of building the Argentine Canal. The controllers ascertained that the fulfilment of the project needed much money and would inflict England great losses. Robert Chiltern is going to make a speech in the parliament and emphasize the inexpediency of building the Canal. But Robert's honest intentions contradict Mrs. Cheveley's aspirations. Having listened to Baron Arnheim's advice, she invested a large sum of money for the mentioned project. As its liquidation is unprofitable for her Lora does her best to persuade the Deputy Minister not to make a planned speech in the parliament: "I want you to withdraw the report that you had intended to lay before the House, on the ground that you have reasons to believe that the Commissioners have been prejudiced of misinformed, or something. Then I want you to say a few words to the effect that the Government is going to reconsider the question, and that you have reason to believe that the Canal, if completed, will be of great international value» [28, p. 23].

Mrs. Cheveley tries to conclude a mutually beneficial agreement with Robert. But sir Robert Chiltern doesn't intend accepting the received proposal. Realizing that she won't manage to get on well with the official with the help of corrupt practices Lora Cheveley resorts to blackmail. She knows some secret information about the beginning of the clerk's career: "I realize that I am talking to a man who laid the foundation of his fortune by selling to a Stock Exchange speculator a Cabinet secret» [28, p. 24]. Lora manages to gain psychological advantage over Robert for some time. The Under-Secretary for Foreign Affairs understands that he is in a deplorable condition, loses his peace of mind and balance. Finally Chiltern promises Mrs. Cheveley to support the Argentine speculation to save his prestige and career.

Lady Chiltern blames her husband's intention. Gertrude is dissatisfied with the change of Robert's previous decision. She appeals to his conscience and sense of moral obligations:

«Lady Chiltern. Compromise? Robert, why do you talk so differently tonight from the way I have always heard you talk? Why are you changed?

Sir Robert Chiltern. I am not changed. But circumstances alter things.

Lady Chiltern. Circumstances should never alter principles!» [28, p. 34].

Gertrude's ethical virtues cause a great emotional influence on Robert. He realizes the errancy of hushing up of the terrible truth about the start of his career. Mrs. Chiltern drastically rejects compromises Robert insists on. She praises his spiritual generosity and is sure that the atmosphere of England's political life became more honest due to her husband's incorruptibility, disinterestedness. O. Wilde as well as I. Karpenko-Karyi in the comedy "The Sea of Life» depicted the state of the woman's soul, the motivation of her behaviour. Concentrating attention on the problem of fidelity and generosity, the playwrights represented the psychology of a woman in her socio-ethical modifications. These parameters of internal collisions in the plays of O. Wilde and I. Karpenko-Karyi are correlative with the direction of the artistic thought of that time. According to V. Vyshynskyi's convincing statement, it is defined by the active mastering of «the collision of the personality with the world way of life full of conflicts. The dramatic collision is fulfilled not only in external quarrels but also in deep psychological confrontation» [3, p. 132].

Reasonable conclusions of the wife persuade the baronet that his decision to support Mrs. Cheveley's swindle is wrong. So he writes Lora a letter rejecting to speak in support of the dishonest project. He will be able to save his family happiness in such a way:

«Sir Robert Chiltern. Oh, love me always, Gertrude, love me always!

Lady Chiltern. I will love you always, because you will always be worthy of love. We must love the highest when we see it!» [28, p. 37].

Robert Chiltern as well as Ivan Baryl'chenko in the comedy "The Sea of Life» are inclined to compromises with their own conscience. But they both can't resist their wives' firmness.

In spite of a difficult position Robert tries to find a way out in his conflict with Mrs. Cheveley. Sir Robert Chiltern decides to send a cipher telegram to his acquaintances in English embassy in Vienne asking to inform him about the details of his opponent's private life. He wishes to get to know some sins of this person the exposure of which she could be afraid of. His friend Lord Goring gives up the idea at once in an ironical way: «Oh, I should fancy Mrs. Cheveley is one of those very modern women of our time who find a new scandal as becoming as a new bonnet, and air them both in the Park every afternoon at five-thirty. I am sure she adores scandals, and that the sorrow of her life at present is that she can't manage to have enough of them» [28, p. 46].

The author describes Robert Chiltern as the person who is a model for other people. The misdealing in his youth is an exception that can't affect the general estimation of this personage. Chiltern led an honest and fair way of life for the rest period of time. Now the disclosure of his former crime could be a big life tragedy for him, a stain on his reputation which generally was irreproachable.

Later Robert Chiltern's wife realizes the real reason for changes of her hus-band's decisions. Mrs. Cheveley tells her about the demands. Lora assures Gertrude that Robert is a dishonourable man. To her mind, he became well-to-do due to ventures, financial intrigues. So the atmosphere in the family becomes tense. Lady Chiltern stops respecting her husband, he becomes disgusting to her. These negative emotions become a result of frustrating her illusions. At that time Robert is not an ideal for her any more.

Having a desire to help his friend, Arthur Goring firmly defends Robert Chiltern's honour during the discussion with Mrs. Cheveley in the library. He doesn't agree with Lora who considers that she knows the truth of the beginning of the Under-Secretary for Foreign Affairs' political life. Goring gives a solid argument: "What you know about him is not his real character. It was an act of folly done in his youth, dishonourable, I admit, shameful, I admit, unworthy of him, I admit, and therefore ... not his true character» [28, p. 88]. Suddenly a young lord notices a bracelet on Mrs. Cheveley's hand which she stole ten years ago. As Goring had chosen that wedding present for his cousin himself, 
it wasn't difficult for him to identify it. Threatening to inform the police about the theft, he took the letter with the help of which Lora had blackmailed Robert Chiltern and saved his friend from a public scandal. Having solved the problem in such a way, Chiltern continued working as a politician, he was proposed the position of the Minister. Gertrude forgave her husband a great mistake of his youth.

The episodes of the play in which Lord Caversham's care for his son's future married life is depicted certify $\mathrm{O}$. Wilde's outstanding humorous gift. The dialogue between the father and the son in which Caversham doesn't consider that it is reasonable to take into consideration the heir's thought about choosing his would-be wife is full of laughter:

«Lord Goring [expostulating]. My dear father, if I am to get married, surely you will allow me to choose the time, place, and person? Particularly the person.

Lord Caversham [testily]. That is a matter for me, sir. You would probably make a very poor choice. It is I who should be consulted, not you. There is property at stake. It is not a matter for affection. Affection comes later on in married life.

Lord Goring. Yes. In married life affection comes when people thor-oughly dislike each other, father, doesn't it?» [28, p. 78].

The quoted dialogue shows that «the main reason for appearing comic effect in life and art is the inherent contradiction of things and phenomena. Non-conformity, non-agreement, a combination of contrasting concepts are the points that produce the element of laughter» [17, p. 47].

In B. Shaw's comedy "Arms and the Man" the differences between the individual adequate world view and social madness are compared in a contrast way. Important political, ideological and moral problems of the epoch are raised in the play. The main idea of the comedy is to reveal the absurdity of the armed confrontation between the Bulgarian and Serbian nations.

A notable fact: B. Shaw in his dramas represented complex processes of the analyzed epoch in the light of inevitable changes. A. Anikst stated this opinion: "Each epoch creates a new way of looking at the world» [1, p. 284]. B. Shaw's new ideas resulted not only the depiction of the society, but influenced the state of the human soul. The playwright created various conflict situations for revealing the characters of the personages using irony, humour, satire, sarcasm. According to P. Balashov's point of view, sharp conflicts used as a basis of B. Shaw's works contribute to "the detailed disclosure of correctly chosen and distinctly rendered human characters: heroes of a play are shown as living beings, they act in typical circumstances that allow to reveal the monstrosity of human relations in the world of acquisition» [2, p. 99].

Depicting captain Bluntschli, one of the principal characters of the comedy "Arms and the Man", the author showed him not as a typical military man. In contrast to courageous and strict soldiers, hardened in numerous battles, Raina Petkoff's surprising guest turned out to be a coward. When Raina sat accidentally on the pistol and cried out in her fright he ran to the opposite side of the room. The flight for Bluntschli is a common way of defence. The captain doesn't use his weapons very often. He even has no cartridges. He argues eloquently their unnecessity during a battle: "I've no ammunition. What use are cartridges in battle? I always carry chocolate instead; and I finished the last cake of that hours ago» [27, p. 25].

The image of Bluntschli is shown in different ways. On the one hand, the captain's behaviour causes comic effect, on the other hand, the reader feels a sympathy for him. Describing that figure the playwright revealed the drama of the person who was born for an active way of life but was involved in military operations of foreign nations. Captain Bluntschli as well as Robert Chiltern in the play "An Ideal Husband» by O. Wilde belongs to that category of B. Shaw's heroes who, according to P. Letnianchyn's opinion, "resist the world of the truth based on dogmatic ethical ideas incompatible with the personal morality» [12, p. 24].

The English dramatist analyzed in detail that Bluntschli's convictions became the result of the failure of his romantic illusions. The Swiss officer's strange behaviour in Petkoffs' house is explained by the author on the basis of the detailed description of the character's previous way of life. In the childhood captain Bluntschli was fond of travelling. He escaped from his father's house to broaden his mind. Later he joined the army though he could work at his rich father's enterprises. Bluntschli joined the Serbian army voluntarily and was the only Swiss among Austrian officers. At that time he totally changed his world outlook. During wars suffering poverty and disastrous situations the captain realized the absurdness of his young dreams, blamed innocent people's deaths. Having taken part in numerous battles his only desire was to live a civil life and become a free citizen in the long run.

Major Saranoff also understood the irrationality of international aggression. So this hero of the Bulgarian army became disappointed in the expediency of the career of an army man and sent in his resignation. In this context the remark of Raina's fiancé deserves attention: «I am no longer soldier. Soldiering, my dear madam, is the coward's art of attacking mercilessly when you are strong, and keeping out of harm's way when you are weak. That is the whole secret of successful fighting. Get your enemy at a disadvantage; and never, on any account, fight him on equal terms» [27, p. 42-43]. Depicting the behaviour, cultural-intellectual values, speech of Raina Petkoff, captain Bluntschli, Sergius Saranoff, the recipient observes the main principles of B. Shaw's ideas about the character of a new drama who has a decisive intention of living with dignity in the world.

Conclusions. In the social comedy «The Wise Man and the Fool» by I. Karpenko-Karyi moral-ethical values of the personages are portrayed in a contrast way describing social and cultural relations of people in the late 19th and early 20th centuries that are of typical nature. In contrast with this play the main characters of the comedies "An Ideal Husband" and "Arms and the Man" revalue their life positions in the light of interpretation of the situational comicality. O. Wilde and B. Shaw reflected a close connection of the situational comicality with elements of life dramatic effect asserting vital, active way of living but not a passive result.

In the comedy "An Ideal Husband» the specificity of ethnic-cultural identity of English national humour is defined. The characters' speech shows 
the joking spirit of the nation. In the personages' discussions in the plays of O. Wilde and B. Shaw mockery, irony, sharp wit are concealed and become a peculiar form of consolidation of a free person's rights, his protest against his own enthralment. Robert Chiltern, Arthur Goring, Raina Petkoff, captain Bluntschli, Sergius Saranoff reveal alogisms of customary and ordinary things in life, laugh at the absurdness of the established stereotypes. Being noble, the above-mentioned literary personages re- flect dominant features of the national character, oppose moral degradation, self-adoration, vanity of the mercantile part of the society.

The English playwrights established innovative tendencies of the psychological character formation in the analyzed plays, denoted the importance of moral values that contributed to the deep depiction of subconsciousness concerning the realization of the human fate and comprehension of the surrounding world.

\section{References:}

1. Anykst, A. (1988). Teoryya dramy na Zapade vo vtoroy polovyne XIX veka [The Theory of Drama in the West in the Second Half of the $19^{\text {th }}$ Century]. Moskva: Nauka, $312 \mathrm{p}$.

2. Balashov, P.S. (1982). Khudozhestvennyy myr Bernarda Shou [Bernard Shaw's Literary World]. Moskva: Khudozh. lyt., $328 \mathrm{p}$.

3. Vyshyns'kyy, V. (2006). Gerhart Hauptman: zhanrovo-styl'ovi osoblyvosti dramy: monohrafiya [Gerhart Hauptmann: Genre and Style Peculiarities of the Drama: monograph]. Drohobych: Kolo, $174 \mathrm{p}$.

4. Zakharchenko, A.V. (2007). Ideyno-khudozhni shukannya v ukrayins'kiy dramaturhiyi kintsya XIX - pochatku XX stolittya (problematyka, zhanry, kharaktery) [Idea-literary Research in Ukrainian Dramatic Art in the Late $19^{\text {th }}$ and Early $20^{\text {th }}$ Centuries (Problems, Genres, Characters)]: kand. filol. nauk: 10.01.01 / Kyivs'kyy natsional'nyy un-t im. Tarasa Shevchenka. K., 210 p.

5. Zymomrya, M. (2007). Model'nyy svit osobystosti u dramakh Bernarda Shou, Ivana Franka, Volodymyra Vynnychenka [Model World of a Personality in the Dramas of Bernard Shaw, Ivan Franko, Volodymyr Vynnychenko]. Letnyanchyn P. Osobystist'u dramakh Bernarda Shou, Ivana Franka, Volodymyra Vynnychenka: monohrafiya. Drohobych: Surma, pp. 181-185.

6. Karpenko-Karyy, I. (1989). Dramatychni tvory [Dramatic Works] / vstup. st., uporyad. i prymit. R.Ya. Pylypchuka; red. S.D. Zubkov. Kyiv: Nauk. dumka, 608 p.

7. Karpenko-Karyy, I. (1961). Tvory : v 3 t. [Works : in 3 vol.]. Kyiv: Derzhavne vyd-vo khudozhn'oyi literatury, vol. 3, $459 \mathrm{p}$.

8. Kyrchiv, R.F. (1961). Komediyi Ivana Franka [Ivan Franko's Comedies]. Kyiv: Vyd-vo Akad. nauk URSR, 100 p.

9. Kropyvnyts'kyy, M.L. (1982). P'yesy [Plays]. Kyiv: Dnipro, 368 p.

10. Kutoyan, A.K. (2007). Kompozytsiyno-movlennyevi zasoby stvorennya komichnoho v teksti anhliys'koyi komediyi [Contexture-speech Devices of Comic Effect Formation in the Text of the English Comedy]: avtoref. dys. ... kand. filol. nauk: 10.02.04 / Kharkivs'kyy natsional'nyy un-t im. V.N. Karazina. Kh., 19 p.

11. Lanhlad, Zh. (1999). Oskar Uayl'd, yly Pravda masok [Oscar Wilde or the Truth of Masks] / perevod s frants. V.Y. Hryhor'eva; predysl. A.M. Zvereva. Moskva: Molodaya hvardyya; Palympsest, 325 p.

12. Letnyanchyn, P. (2007). Osobystist' u dramakh Bernarda Shou, Ivana Franka, Volodymyra Vynnychenka: monohrafiya [The Issue of Personality in the Dramas of Bernard Shaw, Ivan Franko, Volodymyr Vynnychenko: monograph]. Drohobych: Surma, 192 p.

13. Literaturoznavcha entsyklopediya : u 2 t. (2007). [Literary Encyclopedia : in 2 vol.] / avt.-uklad. Yu. Kovaliv. Kyiv: VTS «Akademiya», vol. 1, 608 p.

14. Mayster dramy: Dramatychni tvory I. Karpenka-Karoho (2004): navch. posib. [Master of Drama: I. KarpenkoKaryi's Dramatic Works : educational manual] / uporyad. Chichanovs'koho A.A.; peredm. Dem'yanivs'koyi L.S. Kyiv: Hramota, $496 \mathrm{p}$.

15. Malyutina, N.P. (2006). Ukrayins'ka dramaturhiya kintsya XIX - pochatku XX stolittya: aspekty rodo-zhanrovoyi dynamiky: monohrafiya [Ukrainian Dramatic Art of the Late $19^{\text {th }}$ and Early $20^{\text {th }}$ Centuries: the Aspects of Genre Dynamics: monograph]. Odesa: Astroprynt, $352 \mathrm{p}$.

16. Matyushchenko, A.V. (1996). Osobystisna koliziya v ukrayins'kiy dramaturhiyi pershoyi tretyny XX-ho stolittya [Personal Collision in Ukrainian Dramaturgy of the First Third of the $20^{\text {th }}$ Century]: kand. filol. nauk: $10.01 .01 /$ NAN Ukrayiny. K., 161 p.

17. Minchyn, B.M. (1959). Deyaki pytannya teoriyi komichnoho [Some Aspects of the Theory of Comic Effect]. Kyiv: AN URSR, $238 \mathrm{p}$.

18. Moroz, L.Z. (1994). «Sto rivnotsinnykh pravd». Paradoksy dramaturhiyi V. Vynnychenka [«One Hundred Truths of Equal Value». The Paradoxes of V. Vynnychenko's Dramatic Art]. Kyiv: In-t literatury im. T.H. Shevchenka NAN Ukrayiny, $208 \mathrm{p}$

19. Obraztsova, A.H. (1965). Dramaturhycheskyy metod Bernarda Shou [Bernard Shaw's Dramatic Method]. Moskva: Nauka, 316 p.

20. Panchenko, V.Ye. (2004). Volodymyr Vynnychenko: paradoksy doli i tvorchosti: Knyha rozvidok ta mandrivok [Volodymyr Vynnychenko: Paradoxes of Fate and Works: A Book of Research and Travels]. Kyiv: Tvim inter, 288 p.

21. Prats'ovytyy, V.S. (1999). Natsional'nyy kharakter v ukrayins'kiy dramaturhiyi 20-30-kh rokiv XX stolittya [National Character in Ukrainian Dramaturgy of the 1920s and 1930s]. L'viv: Liha-Pres, $282 \mathrm{p.}$

22. Sokolyanskyy, M.H. (1990). Oskar Uayl'd: Ocherk tvorchestva [Oscar Wilde: Essay of Works]. Kyiv-Odessa: Lybyd', $200 \mathrm{p}$.

23. Stetsenko, L.F. (1969). Dramaturhiya M.P. Staryts'koho [M.P. Starytskyi's Dramatic Art] // Istoriya ukrayins'koyi literatury: u 8 t. T. 4, kn. 2 : Literatura 70-90-kh rokiv XIX st. / O.Ye. Zasenko, N.L. Kalenychenko, A.A. Kaspruk $\mathrm{i}$ in.; vidp. red. O.Ye. Zasenko. Kyiv: Naukova dumka, pp. 327-359.

24. Khorob, S.I. (2013). Model'nyy svit osobystosti (porivnyal'nyy dyskurs u dramakh Ivana Franka, Volodymyra Vynnychenka i Bernarda Shou) [Model World of a Personality (Comparative Discourse in the Dramas of Ivan Franko, Volodymyr Vynnychenko and Bernard Shaw)]. Stepan Khorob. Dialohy u vidsviti slova. Ukrayins'ka dramaturhiya v typolohichnykh zistavlennyakh. Ivano-Frankivs'k: Misto NV, pp. 276-283.

25. Gordon, D.J. (1990). Bernard Shaw and the Comic Sublime. London: Macmillan, 218 p.

26. Henderson, A. (1956). George Bernard Shaw: Man of the Century. New York: Appleton-Century-Crofts, 969 p. 
27. Shaw, G.B. (1961). Arms and the Man. An Anti-Romantic Comedy in Three Acts / introduction and notes by A.C. Ward. London; New York; Toronto: Longmanns, Green and Co in association with Constable and Co Ltd. 118 p. 28. Wilde, O. (2014). An Ideal Husband; The Importance of Being Earnest. Kyiv: Znannia, 222 p.

29. Worth, K. (1984). Oscar Wilde. New York: Grove Press, 199 p.

\section{Список літератури:}

1. Аникст А. Теория драмы на Западе во второй половине XIX века. Москва : Наука, 1988. 312 с.

2. Балашов П.С. Художественный мир Бернарда Шоу. Москва : Худож. лит., 1982. 328 с.

3. Вишинський В. Іергарт Гауптман: жанрово-стильові особливості драми : монографрія. Дрогобич : Коло, 2006.174 с.

4. Захарченко А.В. Ідейно-художні шукання в українській драматургії кінця XIX - початку XX століття (проблематика, жанри, характери) : канд. фрілол. наук : 10.01.01 / Київський національний ун-т ім. Тараса Шевченка. К., 2007. 210 c.

5. Зимомря М. Модельний світ особистості у драмах Бернарда Шоу, Івана Франка, Володимира Винниченка. Летнянчин П. Особистість у драмах Бернарда Шоу, Івана Франка, Володимира Винниченка : монографрія. Дрогобич : Сурма, 2007. С. 181-185.

6. Карпенко-Карий І. Драматичні твори / вступ. ст., упоряд. і приміт. Р.Я. Пилипчука; ред. С.Д. Зубков. Київ : Наук. думка, 1989. 608 с.

7. Карпенко-Карий I. Твори : в 3 т. Київ : Державне вид-во художньої літератури, 1961. Т. 3.459 с.

8. Кирчів Р.Ф. Комедії Івана Франка. Київ : Вид-во Акад. наук УРСР, 1961. 100 с.

9. Кропивницький М.Л. П’еси. Київ : Дніпро, 1982. 368 с.

10. Кутоян А.К. Композиційно-мовленневі засоби створення комічного в тексті англійської комедії : автореф. дис. ... канд. фрілол. наук : 10.02.04 / Харківський національний ун-т ім. В.Н. Каразіна. Х., 2007. 19 с.

11. Ланглад Ж. Оскар Уайльд, или Правда масок / перевод с франц. В.И. Григорьева; предисл. А.М. Зверева. Москва : Молодая гвардия; Палимпсест, 1999. 325 с.

12. Летнянчин П. Особистість у драмах Бернарда Шоу, Івана Франка, Володимира Винниченка : монографія. Дрогобич : Сурма, 2007. 192 с.

13. Літературознавча енциклопедія: у 2 т. / авт.-уклад. Ю. Ковалів. Київ : ВЦ «Академія», 2007. Т. 1. 608 с.

14. Майстер драми: Драматичні твори І. Карпенка-Карого : навч. посіб. / упоряд. Чічановського А.А.; передм. Дем'янівської Л.С. Київ : Грамота, 2004. 496 с.

15. Малютіна Н.П. Українська драматургія кінця XIX - початку XX століття: аспекти родо-жанрової динаміки : монографія. Одеса : Астропринт, 2006. 352 с.

16. Матющенко А.В. Особистісна колізія в українській драматургії першої третини XX-го століття : канд. фрілол. наук : 10.01.01 / НАН України. К., 1996. 161 с.

17. Мінчин Б.М. Деякі питання теорії комічного. Київ : АН УРСР, 1959. 238 с.

18. Мороз Л.З. “Сто рівноцінних правд». Парадокси драматургії В. Винниченка. Київ : Ін-т літератури ім. Т.Г. Шевченка НАН України, 1994. 208 с.

19. Образцова А.Г. Драматургический метод Бернарда Шоу. Москва : Наука, 1965. 316 с.

20. Панченко В.Є. Володимир Винниченко: парадокси долі і творчості: Книга розвідок та мандрівок. Київ : Твім інтер, 2004. 288 c.

21. Працьовитий В.С. Національний характер в українській драматургії 20-30-х років ХХ століття. Львів : ЛігаПрес, 1999. 282 с.

22. Соколянский М.Г. Оскар Уайльд: Очерк творчества. Киев-Одесса : Лыбидь, 1990. 200 с.

23. Стеценко Л.Ф. Драматургія М.П. Старицького // Історія української літератури : у 8 т. Т. 4, кн. 2 : Література 70-90-х років XIX ст. / О.Є. Засенко, Н.Л. Калениченко, А.А. Каспрук і ін.; відп. ред. О.Є. Засенко. Київ : Наукова думка, 1969. С. 327-359.

24. Хороб C.I. Модельний світ особистості (порівняльний дискурс у драмах Івана Франка, Володимира Винниченка і Бернарда Шоу). Степан Хороб. Діалоги у відсвіті слова. Українська дралатургія в типологічних зіставленнях. Івано-Франківськ : Місто НВ, 2013. С. 276-283.

25. Gordon D.J. Bernard Shaw and the Comic Sublime. London : Macmillan, 1990. 218 p.

26. Henderson A. George Bernard Shaw: Man of the Century. New York : Appleton-Century-Crofts, 1956.969 p.

27. Shaw G.B. Arms and the Man. An Anti-Romantic Comedy in Three Acts / introduction and notes by A.C. Ward. London; New York; Toronto: Longmanns, Green and Co in association with Constable and Co Ltd, 1961.118 p.

28. Wilde O. An Ideal Husband; The Importance of Being Earnest. Kyiv : Znannia, 2014. 222 p.

29. Worth K. Oscar Wilde. New York : Grove Press, 1984. 199 p. 